\title{
Combined Abundance of All
} Vulnerable Marine Ecosystem Indicator Taxa Inadequate as Sole Determiner of Vulnerability, Antarctic Peninsula

OPEN ACCESS

Edited by:

Rowan Trebilco,

Centre for Marine Socioecology, Australia

Reviewed by: Stefano Schiaparelli,

University of Genoa, Italy Anton Pieter Van de Putte, Royal Belgian Institute of Natural Sciences, Belgium

*Correspondence:

Susanne J. Lockhart SouthernBenthics@outlook.com

Specialty section: This article was submitted to

Marine Conservation and Sustainability, a section of the journal

Frontiers in Marine Science

Received: 29 June 2020 Accepted: 10 August 2021 Published: 24 September 2021

Citation: Lockhart SJ and Hocevar J (2021) Combined Abundance of All

Vulnerable Marine Ecosystem Indicator Taxa Inadequate as Sole Determiner of Vulnerability, Antarctic Peninsula. Front. Mar. Sci. 8:577761. doi: 10.3389/fmars.2021.577761

\author{
Susanne J. Lockhart ${ }^{\text {** }}$ and John Hocevar ${ }^{2}$ \\ ${ }^{1}$ California Academy of Sciences, San Francisco, CA, United States, ${ }^{2}$ Greenpeace USA, Washington, DC, United States
}

In order to achieve conservation objectives and preserve the biodiversity of the Southern Ocean, a variety of ecosystems must be protected. This holds especially true for the benthic communities of this region that are characteristically mosaic in their spatial distributions. As such, disparate communities cannot be comprehensively assessed by a single blanket methodology. Herein, evidence appropriate to the diverse characteristics of the communities encountered during a submarine expedition demonstrates the particular vulnerability of four sites that exemplify VMEs as defined by the Commission for the Conservation of Antarctic Marine Living Resources (CCAMLR) and the UN's Fisheries and Agriculture Organization (FAO). Three sites are identified as VMEs based on highly significant abundances of indicator taxa. A fourth is identified based on a high density of cold-water coral taxa, many of which were not observed in abundance at the sites that were triggered as vulnerable by a significantly high abundance of all indicator taxa. The VME at this latter site was richly diverse in coral taxa, many of which are considered particularly vulnerable to climate change, as well as critical for their potential for genuine blue carbon sequestration. As of November, 2018, all four sites are now registered with CCAMLR as VMEs and thus, are afforded protection from all bottom fishing activities. However, if consideration isn't given to the composition and/or diversity of VME indicator taxa present, in addition to overall abundance/density, some of the most vulnerable communities are left at risk. A blanket threshold for all VME taxa adhered to in fisheries management of the Southern Ocean, and other high seas areas, is grossly insufficient. Without taking a more precautionary approach to identifying and protecting VMEs, CCAMLR will not be able to meet its conservation objectives and may even be putting Antarctic fisheries at risk.

Keywords: VME, Vulnerable Marine Ecosystems, cold-water corals, density/abundance thresholds, Antarctica, CCAMLR, submarine, indicator taxa 


\section{INTRODUCTION}

Identification of Vulnerable Marine Ecosystems (VMEs) is a critical component of the management framework for bottom fishing activities. This was brought about largely by the requirements of United Nations General Assembly (UNGA) Sustainable Fisheries Resolution (61/105), aimed at avoiding significant adverse impacts of bottom fishing activities on VMEs in high seas areas (UNGA, 2007).

The relevance of VMEs in the Southern Ocean has never been greater as the Commission for the Conservation of Antarctic Marine Living Resources (CCAMLR) - the international body tasked with managing commercial fishing operations around Antarctica-pursues their 2004 commitment to establish a network of Marine Protected Areas (MPAs) throughout the Southern Ocean (Conservation Measure 91-04; CCAMLR, $2019 b)$. The urgency for protection of this region is underscored by the increased rate of warming that the Peninsula has experienced (Turner et al., 2005, 2016; Jones et al., 2019; Siegert et al., 2019), at a time when industrialized krill fishing along the Antarctic Peninsula is expanding and pressures continue to mount for expansion of commercial benthic long-line fisheries. The combination of accelerating anthropogenic climate change and commercial fishing pressures could lead to a catastrophic collapse of the system if adequate protections are not put in place in time.

The UN Food and Agricultural Organization (FAO) defines marine ecosystems as vulnerable if they have dense threedimensional structures, they experience low levels of natural disturbance and mortality, if their distribution is patchy, or if their component species are fragile (Rogers et al., 2008). Fundamental to vulnerability is resilience and thus, recovery from damage is considered to be extremely slow, or will not occur, if species are rare, unique or exhibit high levels of endemism, or, possess life-history or biological characteristics that include slow growth rates, high longevity, large age of maturity or low recruitment (Rogers et al., 2008).

Following suit, CCAMLR adopted a number of Conservation Measures (CMs), establishing notification procedures and guidelines for the identification and registry of VMEs (Jones et al., 2016; CCAMLR, 2019a,b). Based on the FAO guidelines, a list of taxa that serve as indicators of the presence of a VME is utilized for research purposes and for monitoring commercial benthic by-catch and management of fisheries. Within the CCAMLR Convention Area, fishing vessels (long-liners and pot fisheries) and research vessels are required to monitor and report encounters with VME indicator taxa under Conservation Measures 22-07 and 22-06, respectively (CCAMLR, 2019b). Figure 1 illustrates the two different reporting procedures.

Acceptable supporting evidence has varied in accordance with the diverse methodologies employed by research vessels in the region. Successful methods have included a biomass trigger for invertebrate by-catch during fish surveys (Lockhart and Jones, 2009, 2010; Jones and Lockhart, 2011; Lockhart et al., 2012) and other research activities (Gaitán et al., 2013), population genetics (Chiantore and Vacchi, 2012), as well as in situ photographic observation (Jones and Lockhart, 2011; Lockhart et al., 2012). Fishery-independent Antarctic research surveys and expeditions provide powerful platforms with considerable potential to detect and report encounters of VMEs in the CAMLR Convention Area. As the Commission's VME registry grows, the ability to manage and minimize risk to VMEs in both present and potential future fisheries in the Convention Area is greatly improved, and in turn significantly strengthens the science behind the larger MPA proposals being considered by the Commission. The most relevant of these MPA proposals to the current research is that proposed by the Delegations of Argentina and Chile (2020) in CCAMLR's Planning Domain 1 (D1MPA) which encompasses
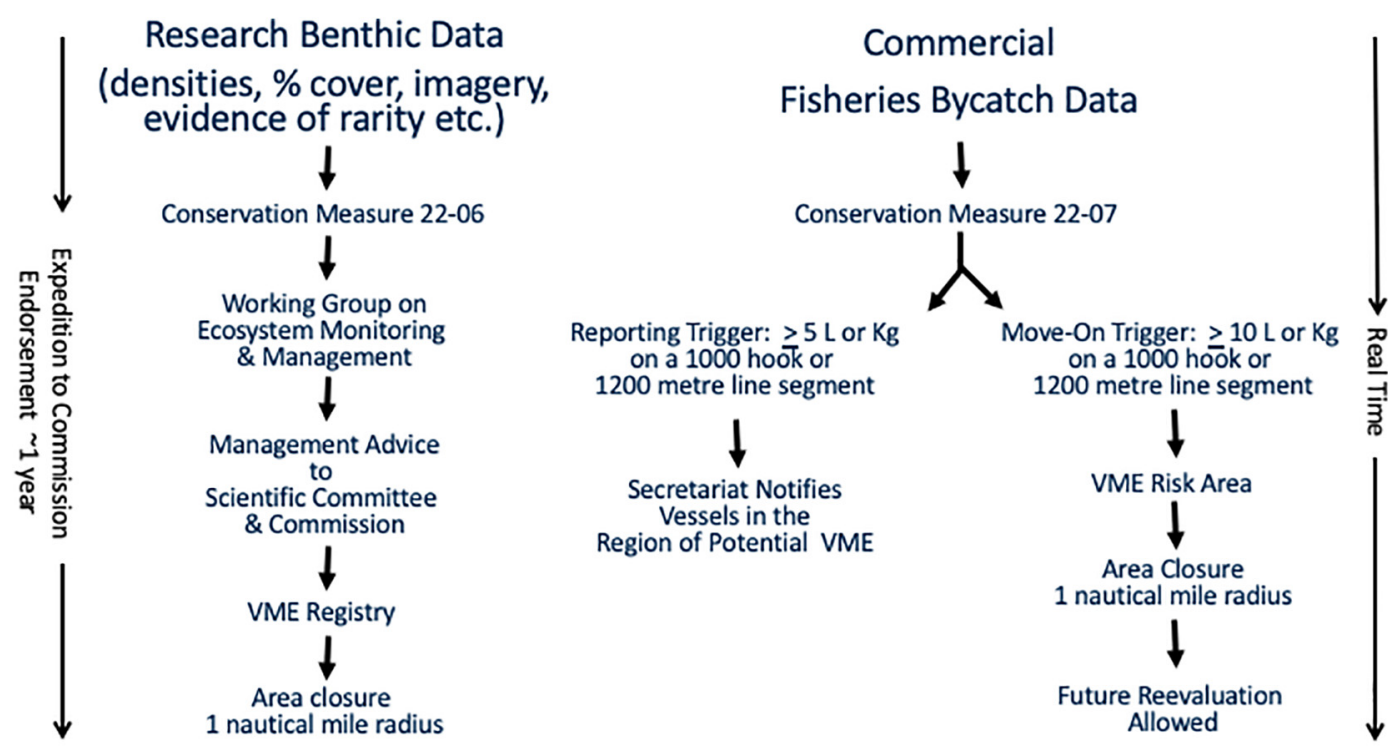

FIGURE 1 | CCAMLR VME reporting and registering process. 
the Western Antarctic Peninsula (WAP). VME coordinates were just one important layer modeled in the development of D1MPA in order to identify areas of priority for protection (Delegations of Argentina and Chile, 2017). Indeed, a recent study unveiled a benthic taxa richness along the WAP that is comparable to values obtained using the same camera system and methodology in the Tropical Eastern Pacific (Friedlander et al., 2020). Facing rapid and dramatic changes due to the impact of climate change, the fragile benthic ecosystems in this region of Antarctica are under considerable threat (Rogers et al., 2019; Siegert et al., 2019).

Fisheries-independent research, especially the availability of direct imagery, possesses great potential to aid in the development of new management and monitoring protocols. CCAMLR has recognized the limitations of the thresholds currently in use for the region for more than a decade (e.g., CCAMLR, 2009, 2019c), and they are not the only fisheries management organization of a large high seas region struggling to set appropriate thresholds (Geange et al., 2020) and develop nonsubjective methodologies to reliably and consistently identify VMEs (Morato et al., 2018). Results from independent research such as are presented here can be used to inform new and more appropriate thresholds in Southern Ocean fisheries management and other high seas regions.
To this end, an expedition in January of 2018 sought to identify VMEs within the D1MPA region, and to follow CCAMLR's current VME proposal procedures, in order to add to the science of benthic layers modeled in support of one of the most critical of the MPA proposals that have yet to be adopted. Our objective was successful; the four sites identified by the methodology herein, received protection the same year (CCAMLR, 2018).

\section{MATERIALS AND METHODS}

\section{Sampling Gear and Location}

Research submarine video survey and sampling was conducted off the Dutch vessel M/Y Arctic Sunrise in January 2018, along the WAP (within CCAMLR statistical Subarea 48.1) by a Dual DeepWorker 2000 submarine (Nuytco Research Ltd.). The Dual DeepWorker 2000 is a two-person, one atmosphere submersible that can operate in depths up to $600 \mathrm{~m}$. Each person has a 24 -inch diameter, acrylic viewing dome, which gives an expansive field of view and is used to enter/exit the submersible ${ }^{1}$. It is equipped with an HD (H.264, Blu-Ray Codec) camera with a 2-point

\footnotetext{
${ }^{1}$ www.nuytco.com
}

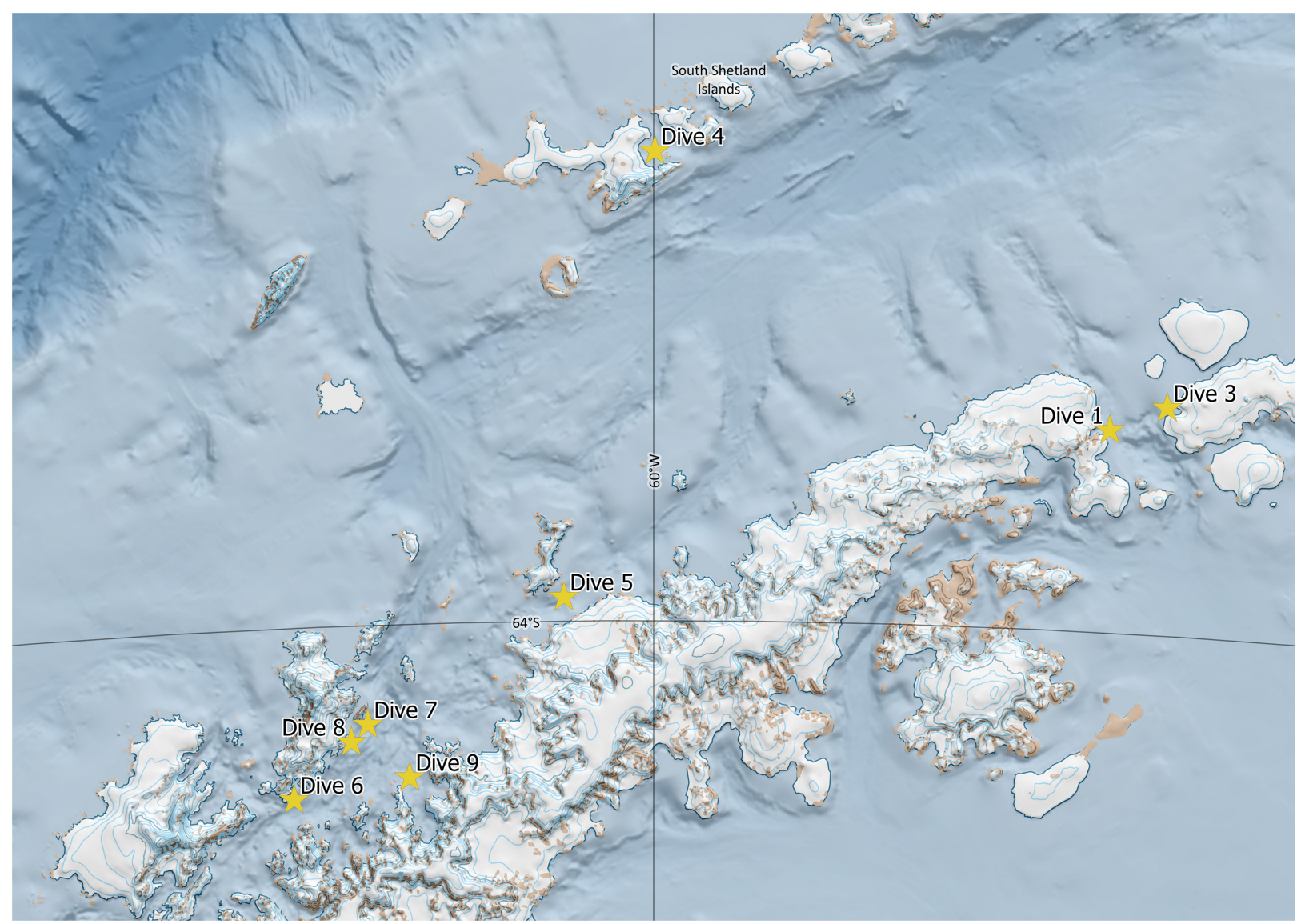

FIGURE 2 | Map of successful dive sites during the January, 2018, M/Y Arctic Sunrise expedition. Generated with QGIS (http://qgis.osgeo.org) software (QGIS Development Team, 2019) using the Quantarctica package provided by the Norwegian Polar Institute. 
laser measurement system set at $20 \mathrm{~cm}$. Benthic invertebrate samples for taxonomic determinations were collected using a HydroNewt Manipulator arm controlled by the pilot via a joystick and are deposited with the California Academy of Sciences (San Francisco).

As stated above, the purpose of the expedition was to explore the seabed and record evidence of any VMEs encountered. Dive sites, therefore, were chosen based on interest and experience (and heavily influenced by sea and ice conditions) and not by following a random survey pattern. An estimate of the number and/or extent of VMEs in the region as a whole was not the objective, and without a random survey pattern it cannot be inferred from the findings herein. However, dives were conducted blind, i.e., the course of the submarine was directed verbally via radio communications with the Nuytco submarine technicians topside according to their own set of safety priorities (e.g., presence of icebergs) and bathymetry, and in the absence of in situ consultation with either the pilot or PAX (i.e., passenger). Control of the Dual Deepworker 2000 is much easier up-slope than down, therefore the submarine was directed along a slowly ascending bathymetry.
For example, we were generally directed diagonally up and along walls and slopes.

All attempts were made by both pilot and PAX to maintain a consistent speed, distance off-bottom and camera angle. However, this is easier said than done, especially in different currents, visibility conditions and along greatly varying bathymetry and substrate type (e.g., presence of silty sediments requiring a more conservative distance off-bottom). These issues are common problems inherent in submersible research (Fillinger and Funke, 2013; Marcon and Purser, 2017) and innovative strategies and software are in constant development in an attempt to address them.

Eight successful dives were accomplished (Figure 2), the details of which are provided in Table 1. This highly selective mode of sampling is non-invasive and results in minimal direct damage to the benthic community, preserving the integrity of any VMEs potentially encountered.

\section{Image Analysis}

Each raw video file was edited in Final Cut Pro $\mathrm{X}$ to remove unusable sequences. Besides descent and ascent, this included any

TABLE 1 | Details of the eight successful submarine dives along the western Antarctic Peninsula and Antarctic Sound.

\begin{tabular}{|c|c|c|c|c|}
\hline & Dive $1^{*}$ & Dive $3^{*}$ & Dive 4 & Dive $5^{\star}$ \\
\hline Date & 19- January-18 & 21-January-18 & 22-January-18 & 24-January-18 \\
\hline Location & Hope bay, Antarctic Sound & Kinnes cove, Antarctic Sound & Moon bay, Livingston Island & Trinity Is., Gerlache Strait \\
\hline Bathymetry & Flat & Wall & Slope and flat & Flat \\
\hline Substrate type & Gravel & Rockface and boulder & Silt & Gravel \\
\hline Start depth (m) & 101 & 331 & 220 & 198 \\
\hline End depth (m) & 110 & 229 & 204 & 203 \\
\hline Depth range (m) & $101-121$ & $229-331$ & $204-222$ & $198-220$ \\
\hline Start coordinates & S63 23.1231; W056 54.8934 & S63 18.5222; W056 32.1546 & S62 34.6316; W059 59.5197 & S63 55.6458; W060 37.1664 \\
\hline End coordinates & S63 23.2110; W056 54.8601 & S63 18.4992; W056 32.2106 & S62 34.5259; W060 00.4323 & S63 55.6692; W060 37.5356 \\
\hline Bottom time (h:m) & $0: 55$ & $0: 48$ & $2: 09$ & $2: 03$ \\
\hline Analysis video length (m:s) & $23: 43$ & $20: 58$ & $28: 13$ & $13: 50$ \\
\hline Time interval analyzed (s) & 60 & 60 & 90 & 60 \\
\hline Number of frames analyzed & 24 & 21 & 19 & 14 \\
\hline \multirow[t]{2}{*}{ Dominant camera angle } & Oblique & Perpendicular & Oblique & Oblique \\
\hline & Dive 6 & Dive $7^{\star}$ & Dive 8 & Dive 9 \\
\hline Date & 25-January-18 & 26-January-18 & 26-January18 & 27-January18 \\
\hline Location & Brabant Is., Gerlache Strait & Lecointe Is., Gerlache Strait & Hunt Is., Gerlache Strait & Charlotte Bay, Gerlache Strait \\
\hline Bathymetry & Steep Slope & Wall & Steep slope & Slight slope \\
\hline Substrate type & Silt & Rockface and boulder & Silt & Silt \\
\hline Start depth (m) & 403 & 566 & 363 & 273 \\
\hline End depth (m) & 223 & 362 & 194 & 275 \\
\hline Depth range (m) & $223-421$ & $362-566$ & $191-366$ & $245-283$ \\
\hline Start coordinates & S64 31.3241; W062 32.5848 & S64 18.0887; W062 00.1773 & S64 21.1708; W062 07.4167 & S64 27.9683; W061 43.2780 \\
\hline End coordinates & S64 31.0951; W062 32.6050 & S64 17.9587; W061 59.9844 & S64 21.0544; W062 07.6337 & S64 27.9242; W061 43.3110 \\
\hline Bottom time (h:m) & $2: 03$ & $2: 10$ & $2: 04$ & $0: 56$ \\
\hline Analysis video length (m:s) & $44: 09$ & $45: 20$ & 39:02 & 25:04 \\
\hline Time interval analyzed (s) & 120 & 120 & 120 & 60 \\
\hline Number of frames analyzed & 23 & 23 & 20 & 26 \\
\hline Dominant camera angle & Perpendicular & Perpendicular & Perpendicular & Oblique \\
\hline
\end{tabular}

$A n$ * denotes VMEs from this research successfully registered with CCAMLR. 
time the submarine was positioned too far off the seabed, camera angle was too extreme for reliable identification, silt obscured the view, or footage was out of focus. In addition, and to reduce bias, sequences where transect travel was paused to report vitals topside, to collect a sample or to photograph taxa or communities of interest, were deleted. Thus, Analysis Video Length is much shorter than Bottom Time (Table 1).

To compare the relative percent abundance of VME indicator taxa to that of non-VME taxa and bare substrate at each site, screenshots were extracted at regular intervals for analysis beginning at 0:00 (m:ss). The interval used for each video (60, 90 , or $120 \mathrm{~s}$ ) depended on the length of the video in order to produce similar sample sizes across sites. The first frame at each of these second time slots was selected unless the quality was poor. In these cases, the clearest frame within the second (s) time slot was chosen.

Each dive's series of screenshots for analysis was then imported into the program, PAPARA(ZZ)I (Marcon and Purser, 2017). Within this program, images were first enhanced by adjusting brightness, contrast and gamma. As recommended by the authors, the usable area was then defined for each individual area. This feature not only allowed the exclusion of dark or blurred edges, but also reduced bias caused by varying camera angles, i.e., where camera angle was oblique over a flat bathymetry, a horizontal rectangle within the lower half of the frame was defined for analysis, and in the case of an oblique angle to a wall, a vertical rectangle on the wall side was defined (Figure 3). Once images were prepared in this way, an array of 100 random points was overlaid. A random (rather than grid) array further

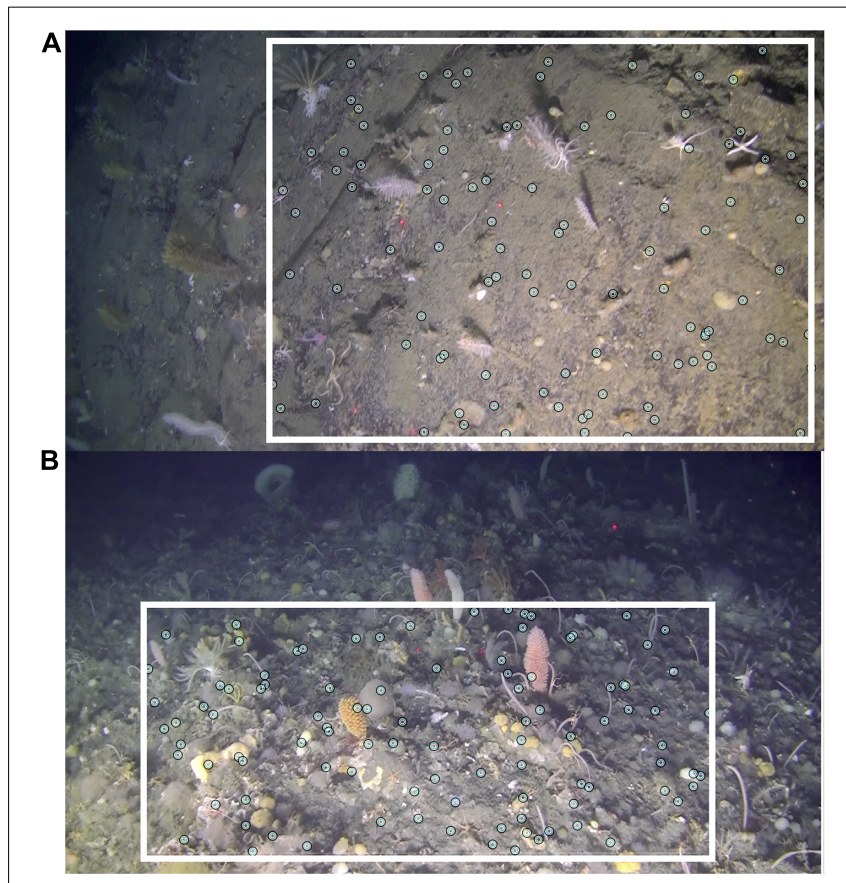

FIGURE 3 | Example of the approach taken to correct for differing camera angles during image analysis using features available in PAPARA(ZZ)I. (A) Wall off Lecointe Is (Dive 7). (B) Flat terrain off Trinity Is (Dive 5). decreased the bias resulting from varying camera angles. Each point in each image was assigned one of three designations: VME indicator taxa, non-VME taxa or bare substrate. Each data point can be assigned multiple input tiers. As such, non-VME taxa were further scored as seaweed, fish or other. Likewise, VME indicator taxa were further scored according to CCAMLR's list of VME indicator taxa with slight modifications to reflect more up-to-date taxonomic nomenclature (Table 2) as accepted in the World Register of Marine Species known as WoRMS ${ }^{2}$ (WoRMS Editorial Board, 2021). The classification rank of the OTUs varied, with some as broad as Phylum (e.g., Bryozoa) and others as specific as Genus (e.g., Acanthogorgia Gray, 1857) depending on the reliability of accurate identification. The abundances of certain VME OTUs of interest were then available for further analysis.

\section{Data Analyses}

The thresholds of VME indicator taxa that commercial fisheries are bound to report, and which signal whether the vessel must

${ }^{2}$ www.marinespecies.org

TABLE 2 | Presence of the various VME indicator taxa at four of the dive sites (see Table $\mathbf{1}$ for details of each site).

\begin{tabular}{lcccc}
\hline Taxon & Dive 1 & Dive 3 & Dive 5 & Dive 7 \\
\hline Hexactinellida (glass sponge) & $\checkmark$ & $\checkmark$ & $\checkmark$ & $\checkmark$ \\
Demospongiae & $\checkmark$ & $\checkmark$ & $\checkmark$ & $\checkmark$ \\
Hydroida & $\checkmark$ & $\checkmark$ & $\checkmark$ & $\checkmark$ \\
Stylasterida (hydrocoral) & & & $\checkmark$ & $?$ \\
Pennatulacea (sea pens) & & & $\checkmark$ & \\
Alcyoniina (soft coral) & & & $\checkmark$ & $\checkmark$ \\
Isididae (bamboo coral) & $\checkmark$ & $\checkmark$ & $\checkmark$ \\
Primnoidae (bottles, fans and whips) & $\checkmark$ & & & \\
Paragorgiidae (bubblegum coral) & & &
\end{tabular}

Chrysogorgiidae (golden coral)

Actinaria (anemones)

Antipatharia (black coral)

Scleractinia (stony coral)

Zoantharia

Brachiopoda (lamp shells)

Bryozoa (lace coral)

Serpulidae

Adamussium colbecki (scallop)

Bathylasmatidae (sessile barnacles)

Stalked crinoids

Cidaroida (pencil urchins)

Basket and Snake stars

Pterobranchia

Ascidiacea (sea squirts)

Chemosynthetic

Xenophyophora

CCAMLR's VME indicator taxa list has been updated here to reflect current taxonomy accepted in WoRMS.

'?' denotes uncertain indentification. 
cease fishing and move from the area, are based on weight of all VME indicator taxa that reach the surface as by-catch combined. Therefore, to determine if any site or sites supported a greater relative percent abundance of all VME indicator taxa compared to others, boxplots were generated.

Determining whether any sites in a particular study support greater relative percent abundance of all VME indicator taxa combined has been established by previous studies (e.g., Lockhart and Jones, 2009; Lockhart et al., 2012) as acceptable methodology by CCAMLR. However, in order to adequately achieve CCAMLR's conservation objectives and preserve the biodiversity of the Southern Ocean, a variety of ecosystems must be protected. This holds especially true for the benthic communities of this region that are characteristically mosaic in their distributions (Gutt et al., 2013). As such, disparate communities cannot be assessed by a single blanket methodology, as explicitly expressed in CCAMLR's Report of the Workshop on Vulnerable Marine Ecosystems (CCAMLR, 2009). While a benthic community may not show an exceptionally high abundance of VME indicator taxa as a whole, it may still support an unusual abundance of a vulnerable taxon that simply does not occur among high-density communities.

Acanthogorgia, Gray, 1857 is an octocoral genus of the Order Alcyonacea (soft corals and gorgonians) with a distinctive gross morphology and whose colonies are large enough so as to provide a robust dataset based on confident identifications. Acanthogorgia, therefore, was chosen as a starting point to further explore the data. A voucher specimen was collected and deposited at the California Academy of Sciences (CASIZ 228493). In order to better understand correlations between various taxa, Pearson's product-moment analyses were conducted.

\section{RESULTS}

\section{Vulnerability Due to High Densities of VME-Indicator Taxa}

Relative percent abundance of VME indicator taxa and bare substrate varied greatly across the dive sites (Figure 4). The substrate at Dive sites 4, 6, 8, and 9 (Livingston Is., Brabant Is., Hunt Is. and Charlotte Bay, respectively), was predominantly silty with scattered small rocks to large boulders on which clusters of VME indicator taxa could be found. Bare substrate and non-VME taxa dominated the relative percent abundance at these sites (Figure 4). In stark contrast, bare substrate at Dive sites 1, 3, and 5 (Hope Bay, Kinnes Cove and Trinity Is, respectively), was not common (Figures 5-7), except where an ice scour zone was crossed during Dive 1 (Figure 5B). The communities at these sites clearly exhibit the high density of VME indicator taxa, as well as the complex three-dimensional structure expected of a typical VME. The deepest site, Dive 7 off Lecointe Is., supported a complex threedimensional structure with a high diversity of coral indicator taxa (Figure 8) but also a high relative percent abundance of bare substrate (Figure 4).

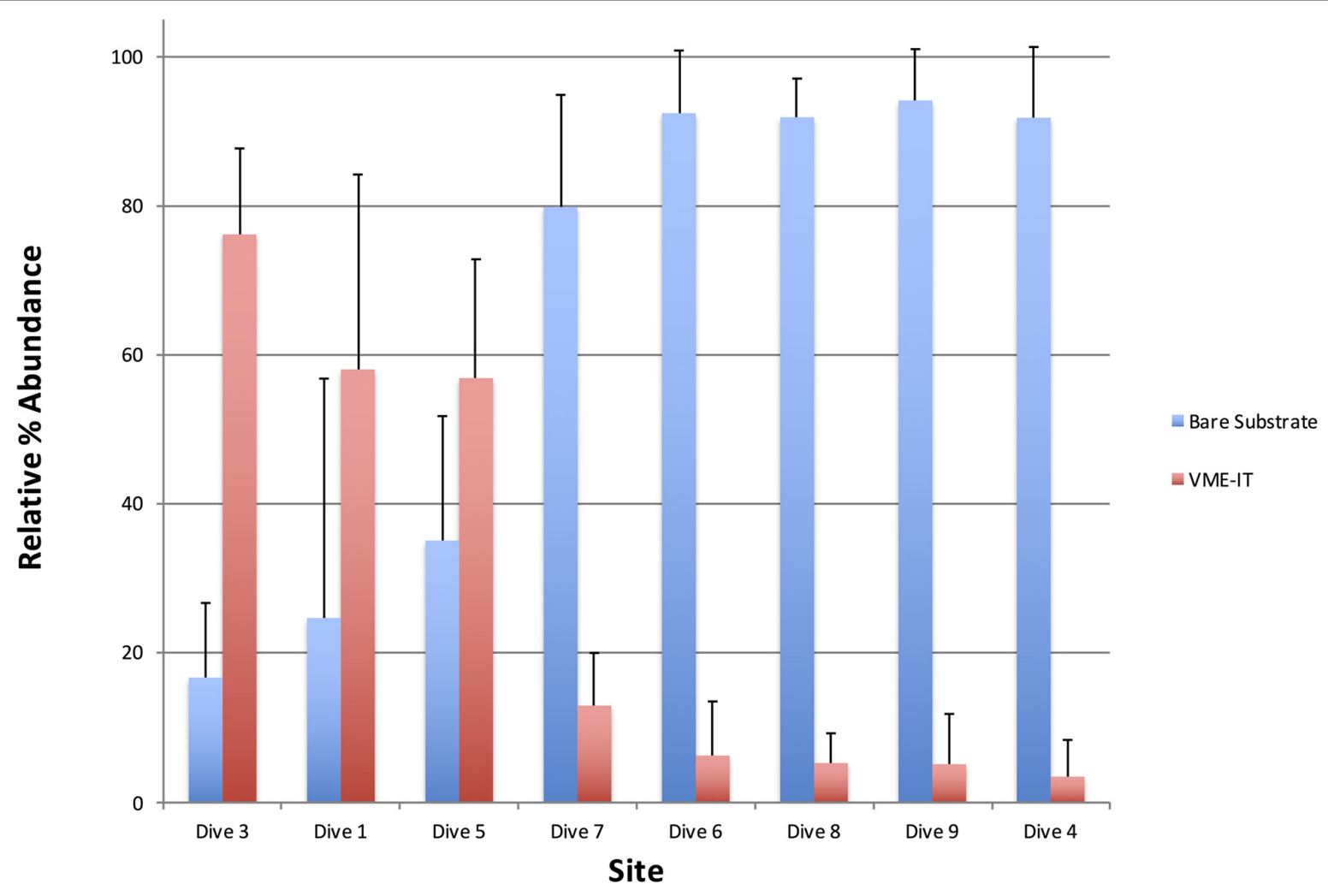

FIGURE 4 | Average relative abundances of VME indicator taxa (VME-IT) and bare substrate as measured in PAPARA(ZZ)I. Bars are standard deviation. 


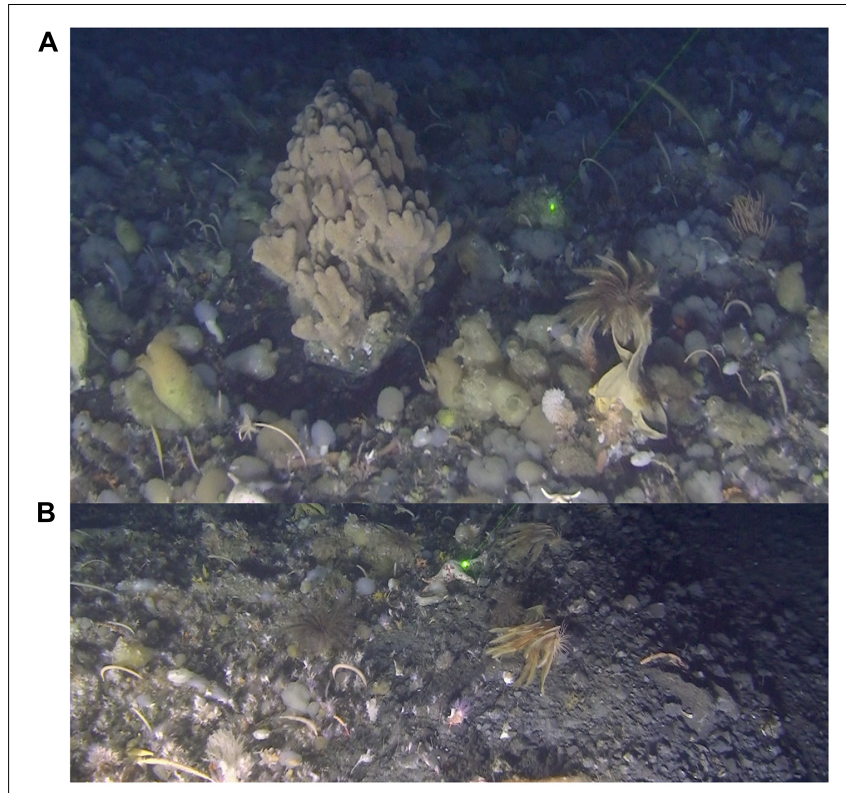

FIGURE 5 | VME at Hope Bay, Antarctic Sound, 100 m (Dive 1). (A) Dense assemblage of VME indicator taxa. (B) The transect at Hope Bay (Dive 1) crossed into a very distinct ice-scour zone.

Boxplots of all VME data (Figure 9) indicate that Dive sites 3 and 1, in the Antarctic Sound, and Dive site 5 off Trinity Island, off the WAP (Figure 2) support greater abundances of VME indicator taxa than the remaining five sites. These sites, therefore, are indicated to be VMEs and are registered as such with CCAMLR.

\section{Vulnerability Due to Alternate Community Characteristics}

Clearly the abundance of Acanthogorgia is much higher off Lecointe Island (Dive 7) than at all other sites (Figure 10A). A Pearson's product-moment correlation analysis revealed a significant positive correlation of Acanthogorgia abundance with depth (Table 3). The abundances of Acanthogorgia were then tested for a correlation with the combined abundances of dense taxa typically found at high density VME sites, i.e., Porifera, Ascidiacea, Bryozoa, and Hydroids-Miscellaneous (This last OTU does not include stylasterids or stalked hydroids which are distinct OTUs). As the focus for this analysis is among VME sites, any sites that were not identified as especially abundant in VME indicator taxa when all taxa are taken into account (see Figure 9) were excluded from these correlation analyses. A significant negative correlation in the abundance of Acanthogorgia with the taxa typically found in high densities in VMEs across the deep site (Dive 7) and the significantly high abundance sites identified above (Dive 1, Dive 3, and Dive 5) was revealed (Table 3).

As the majority of VME thresholds currently set by CCAMLR or in use by its Members to identify VMEs via research are density- or abundance-based, many important taxa and communities may be losing out on essential protections when they do not co-occur with dense or highly abundant taxa such as sponges. Analyses thus far support this concerning scenario for Acanthogorgia. To explore whether such a pattern held true for Antarctic corals in general, first Pearson's productmoment correlations were run between sponges and some coral OTUs (Table 3). Miscellaneous hydroids and primnoids were positively correlated with sponges (weakly and strongly, respectively). As these two taxa are likely to occur with high densities of sponges, they are likely to be protected by a single all-encompassing threshold and were, therefore, excluded from the following analysis. Boxplots comparing VME indicator Cnidaria taxa-excluding miscellaneous hydroids and primnoids-across all sites, shows Dive 7, off Lecointe Island, as noticeably different from all other sites (Figure 10B). In fact, the sites that scored lowest for this broader coral group were the $3 \mathrm{VME}$ sites (1,3, and 5) identified using the conventional all-taxa threshold, along with the most barren dive site (4).

Figure 11 illustrates the compositional heterogeneity of the deeper Dive 7 site compared to the shallower VME sites where

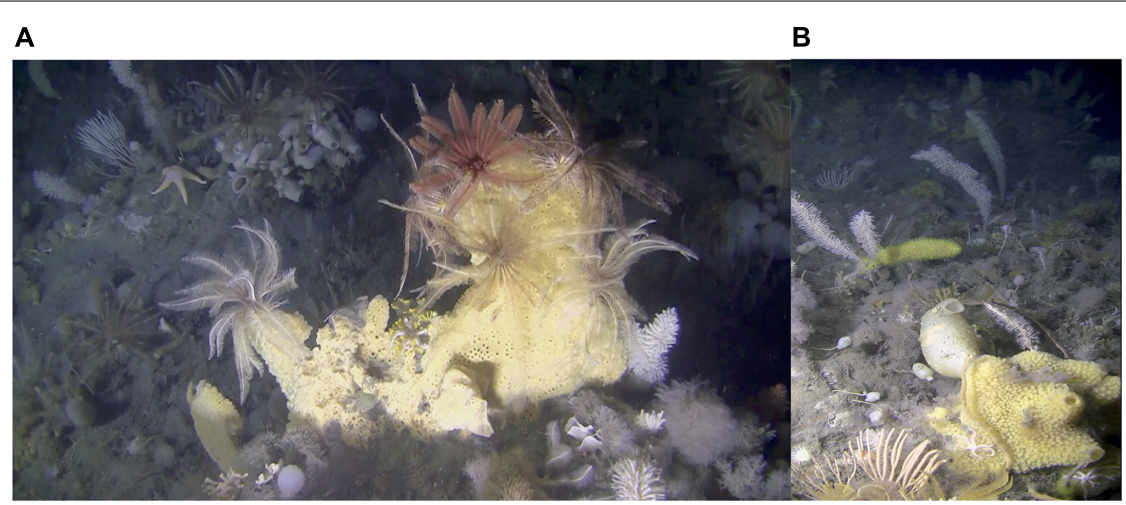

FIGURE 6 | VME at Kinnes Cove, Antarctic Sound (Dive 3). (A) A large hexactinellid Rossella cf. podagrosa cluster in the background and a large yellow Mycale demosponge in the foreground provide habitat for a multitude of organisms, $260 \mathrm{~m}$. (B) The significantly high abundance of VME indicator taxa is illustrated well here; as the view is directed horizontally along the wall, it is possible to see that the structural complexity is great and that it extends beyond the range of visibility, $\sim 300 \mathrm{~m}$. 


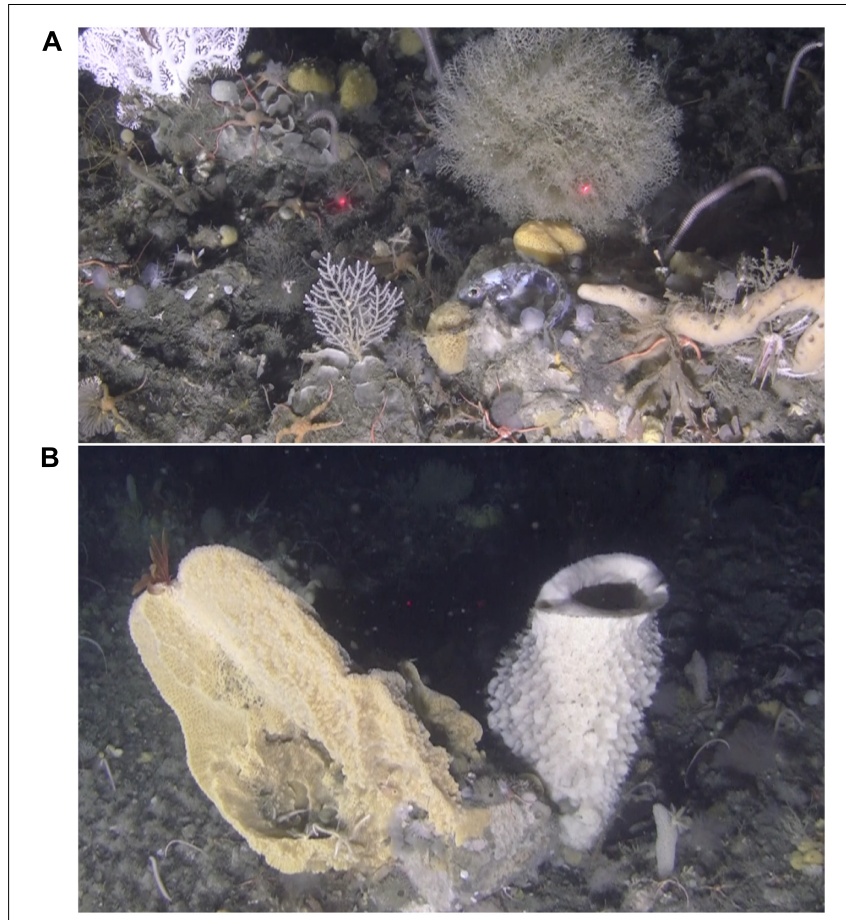

FIGURE 7 | VME off Trinity Island, western Antarctic Peninsula, 200 m (Dive 5). (A) An Antarctic rockcod enjoys ample protection among the complex assemblage at this site. A stylasterid (CITES protected) is seen in the upper left corner. (B) Although the lasers point into the background of this image, they crossed the hexactinellid on the right which measured $>25 \mathrm{~cm}$ in width.

indicator taxa occur at significantly higher abundances. Perhaps even more clearly illustrated by these figures is the striking compositional homogeneity of the sites that trigger VME status by high density and abundance (Dive 1, 3, and 5).

However, corals were not the only noteworthy VME indicator taxon present at this site (Figure 12). The basket star, Gorgonocephalus chilensis (Philippi, 1858), was frequently encountered and not observed at the other locations. The fragility and vulnerability of large balanomorph barnacles is not difficult to perceive (Figure 12E). Sponges, although not remarkably abundant at this deeper site, are an important VME indicator taxon due to the structural complexity and habitat for other organisms that they provide. The hexactinellid, Anoxycalyx joubini (Topsent, 1916), a species that can grow to a considerable size and age (Dayton, 1979, but see also Dayton et al., 2013; Fillinger et al., 2013) is recorded here.

\section{DISCUSSION}

The simplest VME-type community to understand, and therefore one of the most persuasive, is one that is visually and statistically dense with VME-indicator taxa. Here, data are presented that clearly distinguish three dive sites in terms of significantly high abundances of VME indicator taxa. Following protocol, this data was presented as rationale to the CCAMLR Working Group on Ecosystem Monitoring and Management (WG-EMM), Scientific
Committee and finally Commission in 2018. The Commission agreed that there was compelling evidence that the ecosystems encountered by submarine at Kinnes Cove (Dive 3) and Hope Bay (Dive 1) in the Antarctic Sound, and off Trinity Island (Dive 5) along the western Antarctic Peninsula, are indeed vulnerable and in need of protection (CCAMLR, 2018). These three sites are now included on the CCAMLR VME registry (CCAMLR, 2019a) and are protected from commercial bottom fishing activities within a 1 nautical mile radius. As the VME registry grows, so does its usefulness to inform the science behind the network of Marine Protected Areas (MPAs) planned for the region (CM 91-04; CCAMLR, 2019b).

The protection of VMEs and the establishment of a series of MPAs in the Southern Ocean couldn't come at a more critical time. Anthropogenic climate change is causing the retreat of ice shelves and glaciers (Siegert et al., 2019), which in turn provides greater access for fishing and tourism (Barnes and Tarling, 2017; Rogers et al., 2019), both of which are concentrated in the Peninsula region which, until recently (Turner et al., 2016; Jones et al., 2019) experienced the greatest rise in temperatures in the Southern Hemisphere (Turner et al., 2005; Siegert et al., 2019). Thus, the preservation of vulnerable communities as refugia becomes more urgent if its biodiversity is to survive the accelerated rate of glacial carving. Here, the devastation to benthic communities by ice scouring is dramatically illustrated by the imagery from Hope Bay (Figure 5B). The average abundance of VME indicator taxa at Hope Bay is only lower than that at Kinnes Cove because the transect crossed into an ice-scour zone. The demarcation of dense and diverse benthos to bare rubble was stark and extensive, continuing for several hundred meters until ascent was necessary.

Bottom fishing gear, including long-lines, can be even more destructive (Barnes and Tarling, 2017) and in the cold waters of the Southern Ocean where growth is slow, recovery from such a disturbance is predicted to be extremely slow (Gutt, 2001; Rogers et al., 2008). Alarmingly, new research utilizing the Global ARMS (Autonomous Reef Monitoring Structures) protocol in Terra Nova Bay illustrates how recovery in the Southern Ocean is expected to be much slower than in other parts of the World's Ocean (Schiaparelli pers. comm.). Globally standardized stacks of plates are placed on the seabed and are monitored for recruitment over 6 months (Leray and Knowlton, 2015) or preferably 1-3 years (Al-Rshaidat et al., 2016; Danovaro et al., 2016; Pearman et al., 2016; Ransome et al., 2017) and analyzed using comparative imaging, quantifiable biodiversity metrics and DNA sequencing ${ }^{3}$. After 3 years the ARMS plates at Terra Nova Bay remain substantially barren. Although it appears that growth, in at least glass sponges, is far from linear and instead occurs in spurts of recruitment and high growth (Dayton et al., 2013; Fillinger et al., 2013) interrupted by decade(s)-long periods of arrested growth cycles (Dayton, 1979; Gutt and Starmans, 2002), it is clear that recruitment and growth in Antarctic benthos is fickle. Such capricious recruitment and growth in the face of climate-induced increases in larger, and more destructive, iceberg scouring events (whereby larger

${ }^{3}$ www.naturalhistory.si.edu/research/global-arms-program 


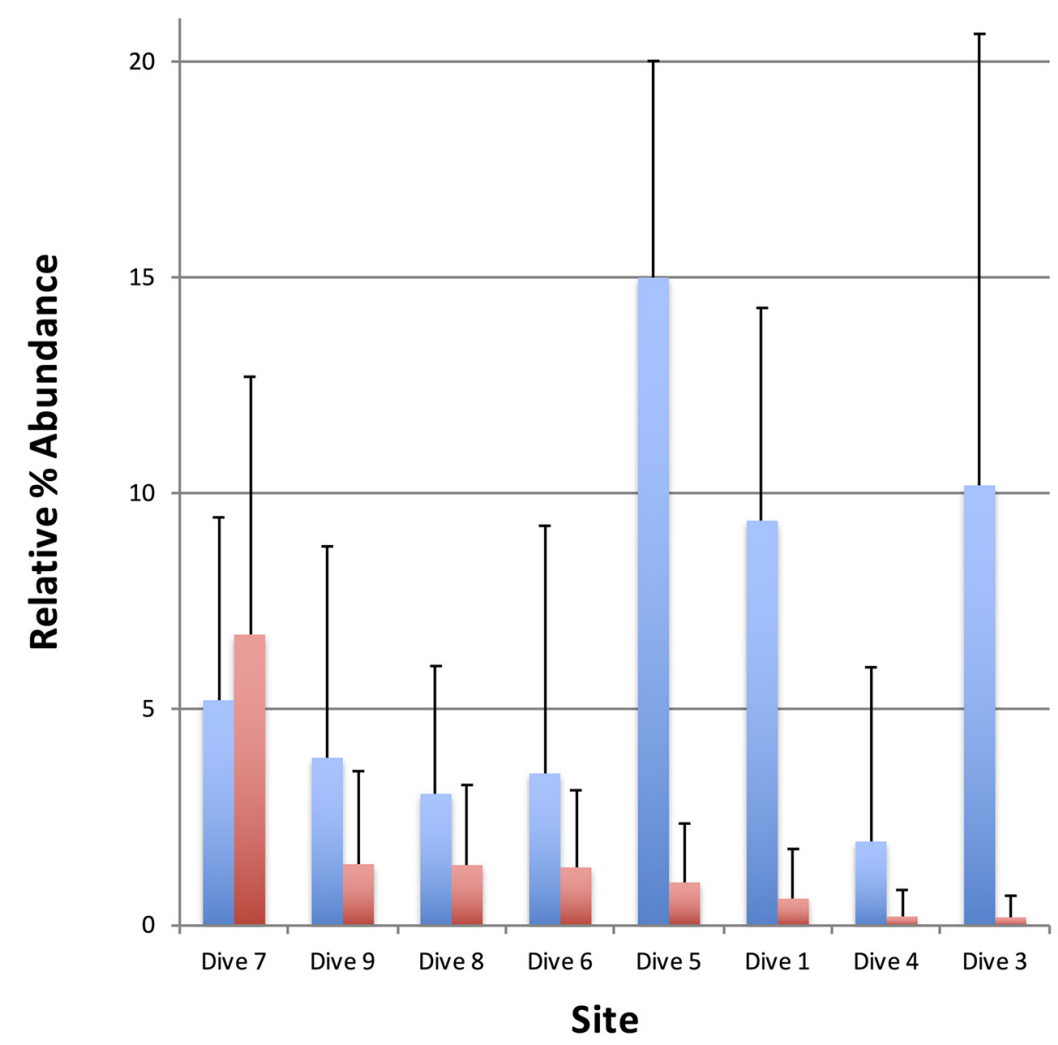

Porifera

- VME Cnidaria (- Misc Hydroids \& Primnoids)

FIGURE 8 | Percentage abundance of all VME indicator Cnidaria taxa excluding miscellaneous hydroids and primnoids (red), which were excluded based on the fact that they are positively correlated with Porifera (blue). Dive site 7 off Lecointe Island in the Gerlache Strait supports significantly more coral taxa than all other sites.

icebergs reach greater depths where the seabed is more likely to host climax communities; Barnes, 2017; Barnes et al., 2018), combined with increasing fishing pressure and access, seriously restricts a VME's resilience and recovery capabilities (Rogers et al., 2019). To this point, the preservation of the dense benthic assemblage at Hope Bay is crucial as a biodiversity refuge as temperatures are expected to rise again in this region which will experience an increase in glacial carving and subsequent iceberg scouring.

Whether by ice scouring or by fishing, disturbance of benthos greatly reduces the carbon storage potential of the Southern Ocean, which may otherwise serve as a critical negative feedback mechanism on climate change (Barnes, 2017; Barnes et al., 2018). Whilst pelagic consumers are predominantly responsible for the conversion of carbon capture to storage, a key role in genuine sequestration of biologically stored carbon (or blue carbon) is played by organisms on the seafloor (Barnes and Tarling, 2017; Barnes et al., 2018; Rogers et al., 2019). Disturbance of the benthos smashes and grinds carbonate bioconstruction, thus recycling carbon within the system rather than true sequestration of carbon out of the system via burial (Barnes, 2017; Barnes et al., 2018).

The estimated blue carbon storage potential of the Southern Ocean has been estimated at as much as $160 \times 10^{6}$ tons per year (Barnes et al., 2018; Gogarty et al., 2020). However, its true global significance, over for example fast growing temperate kelp forests, lies in its genuine sequestration potential because the carbon is stored in skeletal form and thus, is more robust to increasing ocean acidification and more likely to be buried

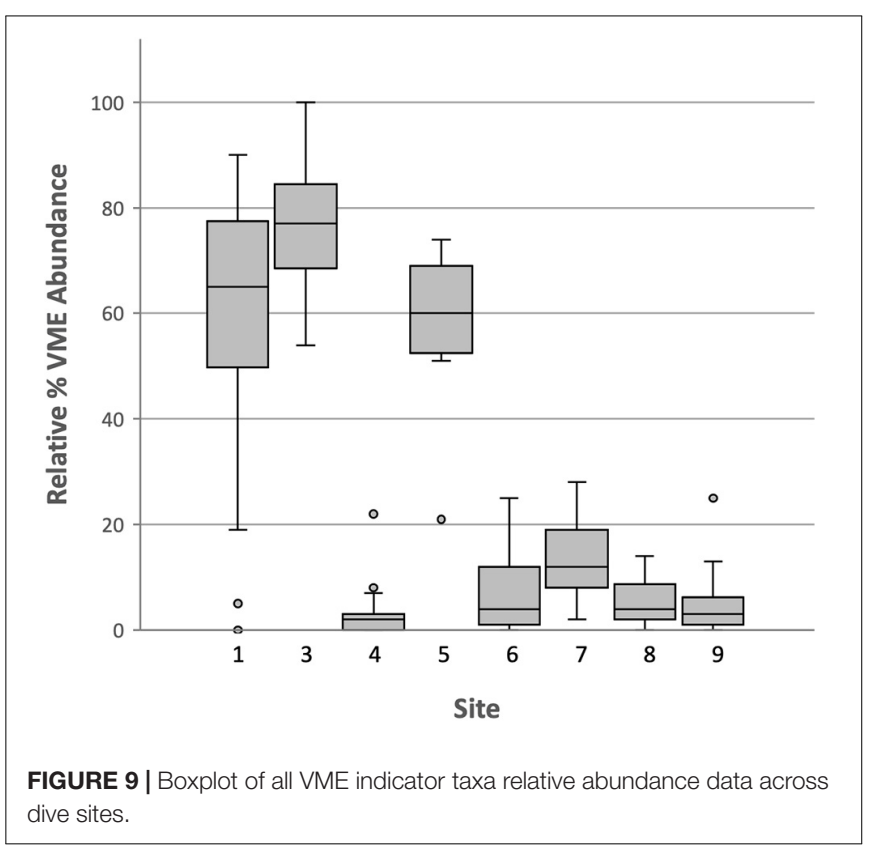



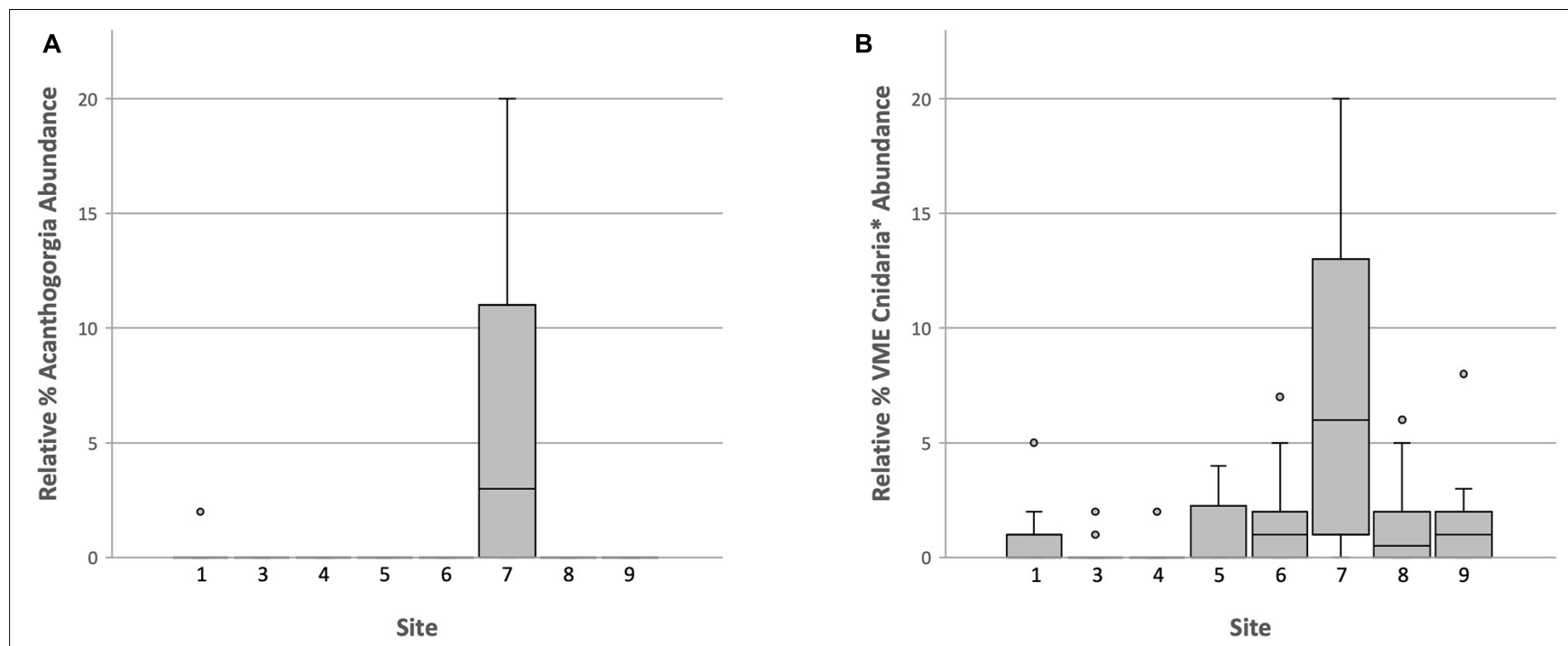

FIGURE 10 | Boxplot of relative abundance data for: (A) The coral, Acanthogorgia and (B) Cnidaria VME taxa, excluding hydroids and primnoids as these cnidarian taxa are found to be positively correlated with sponges (see Table 3).

upon death (Barnes et al., 2018). While glass and demosponges disproportionately contribute to the biomass of Southern Ocean benthos (Lockhart and Jones, 2008; Jones and Lockhart, 2011; Gutt et al., 2013), it is in the abundance and great diversity of carbonate-skeletal corals where the greatest blue carbon potential may truly lie (Barnes, 2017; Barnes et al., 2018).

Moreover, cold-water corals are recognized as an important component of deep-water ecosystems world-wide for their role as ecosystem engineers providing habitat for many other organisms (Rogers et al., 2007, 2008; Miller et al., 2012), and recognition of their vulnerability has put them on the international conservation agenda (Roberts and Cairns, 2014). Corals are diverse (Rogers et al., 2008; Ambroso et al., 2017), extremely slow growing (Roark et al., 2005; Rogers et al., 2007, 2008; Peck and Brockington, 2013; Martinez-Dios et al., 2016) and vulnerable to fishing gear (Rogers et al., 2008; Maynou and Cartes, 2012), and communities can be tens of 1,000 s of years old. Recovery times of populations, therefore, are estimated to be in the 100s or 1,000 s of years (Rogers et al., 2008) and that is especially true

TABLE 3 | Pearson's product-moment correlation outputs.

\begin{tabular}{|c|c|c|c|c|}
\hline Correlation & $\begin{array}{l}\text { Degrees of } \\
\text { freedom }\end{array}$ & $\begin{array}{l}\text { f } t \text {-value } \\
\text { correlation }\end{array}$ & $P$-value & $\begin{array}{l}\text { Correlation } \\
\text { coefficient }\end{array}$ \\
\hline Acanthogorgia vs. depth & 168 & 7.1893 & $<2.039 \mathrm{e}-11$ & 0.4851 \\
\hline Acanthogorgia vs. porifera & 168 & -1.9562 & $<0.0521$ & -0.1492 \\
\hline $\begin{array}{l}\text { Acanthogorgia vs. sponge } \\
\text { VMEs }\end{array}$ & 80 & -4.9869 & $<3.496 \mathrm{e}-06$ & -0.4870 \\
\hline Porifera vs. misc hydroids & 168 & 2.9549 & $<0.0036$ & 0.2223 \\
\hline Porifera vs. primnoids & 168 & 53416 & $<2.96 \mathrm{e}-07$ & 0.3810 \\
\hline $\begin{array}{l}\text { Porifera vs. cnidaria (w/o } \\
\text { misc hydroids and } \\
\text { primnoids) }\end{array}$ & 168 & -0.6542 & $<0.5139$ & -0.0504 \\
\hline
\end{tabular}

Bold denotes significance. for the many brooding species (Ambroso et al., 2017) found in the Southern Ocean. Undisturbed, cold-water coral communities can be as diverse as tropical coral reefs (Barnes and Tarling, 2017)

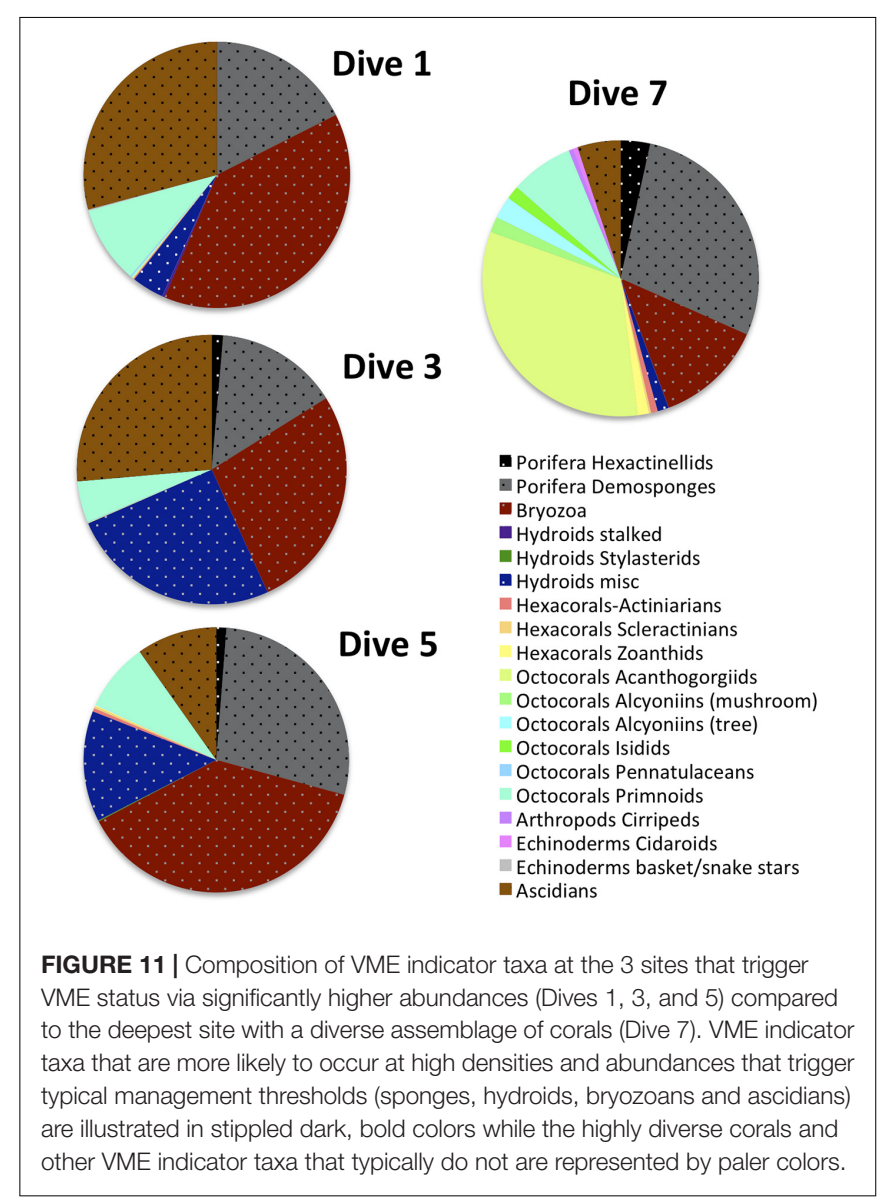



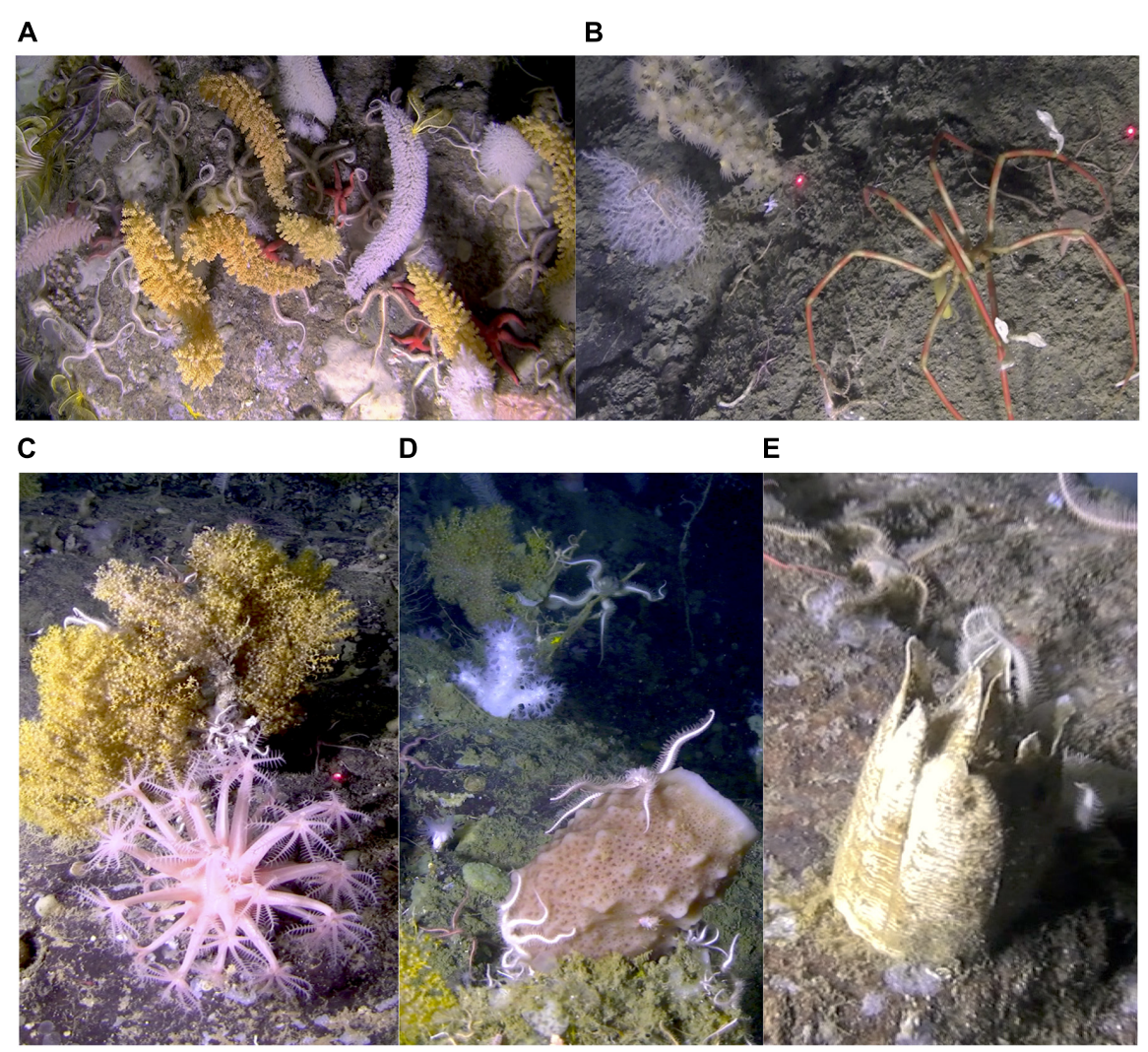

FIGURE 12 | VME off Lecointe Island, Gerlache Strait (Dive 7). (A) Diverse coral assemblage on a boulder $400 \mathrm{~m}$. Three species of primnoid corals; Thouarella cf. grandiffora (orange), T. cf. variablis (white bottle brush) and Dasystenella cf. acanthine (pink). White isidid (bamboo) corals, Primnoisis sp., to the right of the image. Also seen is a small white Gersemia soft coral, upper center. (B) Bamboo coral, like this Primnoisis sp. (white) are notably abundant off Lecointe Island. Zoanthids were only observed at this site; this species, Parazoanthus sp., parasitizes other corals. Lasers $20 \mathrm{~cm}$ apart. (C) Yellow Acanthogorgia sp. and Acanthomastus spp. soft coral. (D) Stony scleractinian corals and in the foreground is a brown hexactinellid sponge. (E) A large sessile barnacle, probably Bathylasma sp.,

measures $>10 \mathrm{~cm}$ high.

and, in the Southern Ocean in particular, such communities can be very dense (e.g., 47 colonies $/ \mathrm{m}^{2}$ in the Weddell Sea; Ambroso et al., 2017).

Coral taxa considered critical include bamboo coral (Isididae). Assemblages of this taxon have been associated with large populations of commercial fish and are especially vulnerable to fishing due to their longevity ( $<100$ years; Roark et al., 2005; Maynou and Cartes, 2012). Bamboo corals are considered especially important as long-term climatic archives (Hill et al., 2011; LaVigne et al., 2011; Sinclair et al., 2011). Here, bamboo corals were encountered more frequently at the deepest dive site off Lecointe Island in the Gerlache Strait (Dive 7) which could not be presented as having significantly great overall abundances of VME indicator taxa because the ecosystem here was not dominated by a dense coverage of sponges, filamentous bryozoans and hydroids.

Another coral taxon that is considered to be particularly vulnerable to the effects of climate change is the stony scleractinian cup corals. Miller et al. (2011) state that scleractinian corals face a loss of up to $70 \%$ of their habitat as the Aragonite Saturation Horizon (below which corals are unable to form calcium carbonate skeletons) rises. They found significant genetic subdivisions among Subantarctic populations that were strongly differentiated by depths consistent with the stratification of Southern Ocean water masses. Miller et al. (2011) therefore concluded that very limited vertical larval dispersal occurs which means that the assumption that shallow occurring populations will act as refuges for deeper water populations is null and void for this taxon. Their findings stress the importance to environmental management of preserving localized populations of Southern Ocean scleractinians not just by region but also by depth.

Although a diversity of corals were common at the three high abundance sites here, some coral taxa, like Acanthogorgia, were not found among the sponges and bryozoans and were only seen in abundance at the deeper site off Lecointe Island. Direct evidence imagery of the impressive coral diversity at this site was presented to CCAMLR in 2018 and the site was declared a VME (CCAMLR, 2018) and joins the other three sites on the registry. However, within the realm of fishing operations, indication of an encounter with a VME is only by passing the one threshold (i.e., $10 \mathrm{~kg}$ or liters; CM 22-07; CCAMLR, 2019b). It is possible that if the Lecointe site was fished, that the Acanthogorgia would be large enough to make it to the surface to trigger the 
threshold and signal move-on but it is certain that the majority of other coral species would not have. Indeed, some of the most vulnerable to disturbance such as the scleractinian stony corals and the stylasterid hydrocorals are also the least likely to make it hundreds of meters to the surface (Rogers et al., 2008). It is clear that CCAMLR's single threshold combining all VME indicator taxa is insufficient and indeed CCAMLR has recognized this insufficiency itself for many years (e.g., CCAMLR, 2009, 2019c). Moreover, it was clearly set out in the scientific guide to the FAO guidelines (Rogers et al., 2008) that separate thresholds for different taxa be used, or alternatively a diversity index be used in combination.

The health of the Southern Ocean, and the Antarctic Peninsula and Weddell Sea regions in particular, has vast and significant consequences for the global ocean, acting as a ventilator, absorbing heat, fresh water and oxygen (Rogers et al., 2019) as it forms bottom water that transports macronutrients northward (Orsi et al., 1999) and imbibes approximately 10\% of anthropogenic carbon dioxide emissions (Hauck et al., 2015). The health of Antarctic benthos, which is largely endemic (Barnes and Tarling, 2017; Barnes et al., 2018) and at threat from invasion of northern species as temperatures rise (Rogers et al., 2019), holds increased significance due to the potential for reliable blue carbon sequestration. Here, one site richly diverse in important coral species did not receive protection based on overall abundances but only by direct imagery evidence. If consideration isn't given to the composition and/or diversity of VME indicator taxa present, in addition to overall abundance/density, some of the most vulnerable communities are left at risk. A blanket threshold adhered to in fisheries management of the Southern Ocean, and other high seas areas, is grossly insufficient and other management strategies must be employed to ensure that a variety of VMEs are protected and the biodiversity of the Southern Ocean better preserved.

The diversity and abundance of VME taxa encountered on this expedition reinforces the case for swift and ambitious action to establish a network of MPAs. Perhaps the most significant results from this expedition were to remind us of how spectacularly different sites can be from one another, even within relatively close proximity, and to confirm that fishery dependent data alone cannot provide us with a comprehensive understanding of the benthic life of the Southern Ocean. These findings make it even clearer than before that the vast majority of VMEs remain undiscovered and unprotected. A more precautionary approach is therefore needed to complement the VME identification process. In order for CCAMLR to meet conservation objectives and to help ensure the future sustainability of the ecosystem upon

\section{REFERENCES}

Al-Rshaidat, M. M. D., Snider, A., Rosebraugh, S., Devine, A. M., Devine, T. D., Plaisance, L., et al. (2016). Deep COI sequencing of standardized benthic samples unveils overlooked diversity of Jordanian coral reefs in the northern Red Sea. Genome 59, 724-737. doi: 10.1139/gen-2015-0208

Ambroso, S., Salazar, J., Zapata-Guardiola, R., Federwisch, L., Richter, C., Maria Gili, J., et al. (2017). Pristine populations of habitat-forming gorgonian species which important commercial fisheries depend, a network of large scale MPAs is urgently needed.

\section{DATA AVAILABILITY STATEMENT}

The raw data supporting the conclusions of this article are available in the Supplementary Material.

\section{AUTHOR CONTRIBUTIONS}

$\mathrm{JH}$ initiated the expedition and edited the manuscript. SL developed and conducted the research with $\mathrm{JH}$ piloting the submarine. SL conducted the analysis and prepared the manuscript. Both authors contributed to the article and approved the submitted version.

\section{FUNDING}

The expedition and research were funded by Greenpeace with support from Jamma International. SL was supported by the Pew Charitable Trusts grant \#32480 for the preparation of this manuscript.

\section{ACKNOWLEDGMENTS}

We thank the captain and crew of the Arctic Sunrise and the Nuytco operations team for their role in this research. We thank expedition leader, Frida Bengtsson. Rachel Downey, Stefano Ambroso, and Eric Lazo-Wasem provided taxonomic assistance. We are grateful to Christopher Jones and Jefferson Hinke for helpful discussions and valuable statistical assistance. Kathrynlynn Theuerkauf and Anne Christianson provided helpful comments on early drafts of the manuscript. Thanks to Anton van de Putte and Stephano Schiaparelli for critiques which greatly improved the paper. A portion of this research and analysis was submitted to CCAMLR in 2018 as an EMM Working Paper (Lockhart and Hocevar, 2018). CCAMLR Working Papers are archived at CCAMLR and are available by request only.

\section{SUPPLEMENTARY MATERIAL}

The Supplementary Material for this article can be found online at: https://www.frontiersin.org/articles/10.3389/fmars. 2021.577761/full\#supplementary-material

on the Antarctic continental shelf. Sci. Rep. 7:12251. doi: 10.1038/s41598-01712427-y

Barnes, D. K. A. (2017). Iceberg killing fields limit huge potential for benthic blue carbon in Antarctic shallows. Global Change Biol. 23, 2649-2659. doi: $10.1111 /$ gcb. 13523

Barnes, D. K. A., Fleming, A., Sands, C. J., Quartino, M. L., and Deregibus, D. (2018). Icebergs, sea ice, blue carbon and Antarctic climate feedbacks. Philos. Trans. A Math Phys. Eng. Sci. 376:20170176. doi: 10.1098/rsta.2017.0176 
Barnes, D. K. A., and Tarling, G. A. (2017). Polar oceans in a changing climate. Curr. Biol. 27, R431-R510. doi: 10.1016/j.cub.2017.01.045

CCAMLR (2009). Report of the Workshop on Vulnerable Marine Ecosystems (La Jolla, CA, USA, 3 to 7 August, 2009). E-SC-XXVIII-A10. Hobart: CCAMLR.

CCAMLR (2018). Thirty-seventh Meeting of the Scientific Committee. SC-CAMLR37. Hobart: CCAMLR.

CCAMLR (2019a). CCAMLR VME Registry. Hobart: CCAMLR.

CCAMLR (2019b). Schedule of Conservation Measures in Force 2019/20. Hobart: CCAMLR.

CCAMLR (2019c). Thirty-eighth Meeting of the Scientific Committee. SC-CAMLR38. CCAMLR: Hobart.

Chiantore, M., and Vacchi, M. (2012). Dense populations of the Antarctic scallop (Adamussium colbecki) in Terra Nova Bay (Subarea 88.1J): potential VMEs adjacent to the Terra Nova Bay ASPA (No. 161). WG-EMM-12/23. CCAMLR: Hobart.

Danovaro, R., Carugati, L., Berzano, M., Cahill, A. E., Carvalho, S., Chenuil, A., et al. (2016). Implementing and innovating marine monitoring approaches for assessing marine environmental status. Front. Mar. Sci. 3:213. doi: 10.3389/ fmars.2016.00213

Dayton, P. K. (1979). "Observations of growth, dispersal and population dynamics of some sponges in McMurdo Sound, Antarctica," in Colloques Internationaux du Centre National de la Recherché Scientifique, eds C. Levi and N. BouryEsnault (Paris: Biologie des Spongiaires) 271-282.

Dayton, P. K., Kim, S., Jarrell, S. C., Oliver, J. S., Hammerstrom, K., Fisher, J. L., et al. (2013). Recruitment, growth and mortality of an Antarctic hexactinellid sponge, Anoxycalyx joubini. PLoS One. 8:e56939. doi: 10.1371/journal.pone.0056939

Delegations of Argentina and Chile (2017). Domain 1 Marine Protected Area Preliminary Proposal PART A-1: Priority Areas for Conservation. SC-CAMLR36/17. CCAMLR: Hobart.

Delegations of Argentina and Chile (2020). Revised Proposal for a Conservation Measure Establishing a Marine Protected Area in Domain 1 (Western Antarctic Peninsula and South Scotia Arc). EC-CC-39-08. CCAMLR: Hobart.

Fillinger, L., and Funke, T. (2013). A new 3-D modelling method to extract substransect dimensions from underwater videos. Ocean Sci. 9, 461-476. doi: 10.5194/os-9-461-2013

Fillinger, L., Janussen, D., Lundälv, T., and Richter, C. (2013). Rapid glass sponge expansion after climate-induced Antarctic ice shelf collapse. Curr. Biol. 23, 1330-1334. doi: 10.1016/j.cub.2013.05.051

Friedlander, A. M., Goodell, W., Salinas-de-León, P., Ballesteros, E., Berkenpas, E., Capurro, A. P., et al. (2020). Spatial patterns of continental shelf faunal community structure along the Western Antarctic Peninsula. PLoS One 15:e0239895. doi: 10.1371/journal.pone.0239895

Gaitán, E., Schejter, L., Giberto, D., Escolar, M., and Bremec, C. (2013). Report of Vulnerable Marine Ecosystems in South Georgia Islands (CCAMLR Subarea 48.3) through Research Dredge Sampling. WG-FSA-13/58. Hobart: CCAMLR.

Geange, S. W., Rowden, A. A., Nicol, S., Bock, T., and Cryer, M. (2020). A data-informed approach for identifying move-on encounter thresholds for Vulnerable Marine Ecosystem indicator taxa. Front. Mar. Sci. 7:155. doi: 10. 3389/fmars.2020.00155

Gogarty, B., McGee, J., Barnes, D. K. A., Sands, C. J., Bax, N., Haward, M., et al. (2020). Protecting Antarctic blue carbon: as marine ice retreats can the law fill the gap? Clim. Policy 20, 149-162. doi: 10.1080/14693062.2019.1694482

Gray, J. E. (1857). Description of a new genus of Gorgoniadae. Proc. Zool. Soc. Lond. $1857,128-129$.

Gutt, J. (2001). On the direct impact of ice on marine benthic communities, a review. Polar Biol. 24, 553-564. doi: 10.1007/s003000100262

Gutt, J., Barnes, D., Lockhart, S. J., and van de Putte, A. (2013). Antarctic macrobenthic communities: a compilation of circumpolar information. Nat. Conserv. 4, 1-13. doi: 10.3897/natureconservation.4.4499

Gutt, J., and Starmans, A. (2002). "Quantification of iceberg impact and benthic recolonisation patterns in the Weddell Sea (Antarctica)," in Ecological Studies in the Antarctic Sea Ice Zone, eds W. E. Arntz and A. Clarke (Berlin: Springer), 210-214. doi: 10.1007/978-3-642-59419-9_27

Hauck, J., Völker, C., Wolf-Gladrow, D. A., Laufkötter, C., Vogt, M., Aumont, O., et al. (2015). On the Southern Ocean $\mathrm{CO}_{2}$ uptake and the role of the biological carbon pump in the $21^{\text {st }}$ century. Global Biogeochem. Cycles 29, 1451-1470. doi: $10.1002 / 2015$ GB005140
Hill, T. M., Spero, H. J., Guilderson, T., Clague, D., Macalello, S., and Jang, N. (2011). Temperature and vital effect controls on bamboo coral (Isididae) isotope geochemistry: a test of the "lines method". Geochem. Geophys. Geosyst. 12, 1-14. doi: 10.1029/2010GC003443

Jones, C. D., and Lockhart, S. J. (2011). Detecting Vulnerable Marine Ecosystems in the Southern Ocean using research trawls and underwater imagery. Mar. Policy 35, 732-736. doi: 10.1016/j.marpol.2011.02.004

Jones, C. D., Lockhart, S. J., and Ramm, D. (2016). “Antarctic and Southern Ocean," in Vulnerable Marine Ecosystems: Processes and Practices in the High Seas, eds A. B. Thompson, J. S. Sanders, M. Tandstad, F. Carocci, and J. Fuller (Rome: FAO Fisheries and Aquaculture), 159-176.

Jones, M. E., Bromwich, D. H., Nicolas, J. P., Carrasco, J., Plavcová, E., Zou, X., et al. (2019). Sixty years of widespread warming in the southern middle and high latitudes (1957-2016). J. Clim. 32, 6875-6898. doi: 10.1175/JCLI-D-18-0565.1

LaVigne, M., Hill, T. M., Spero, H. J., and Guilderson, T. P. (2011). Bamboo coral $\mathrm{Ba} / \mathrm{Ca}$ : calibration of a new deep ocean refractory nutrient proxy. Earth Planet. Sci. Lett. 312, 506-515. doi: 10.1016/j.opsl.2011.10.013

Leray, M., and Knowlton, N. (2015). DNA barcoding and metabarcoding of standardized samples reveal patterns of biodiversity. Proc. Natl. Acad. Soc. U. S. A. 112, 2076-2081. doi: 10.1073/pnas.1424997112

Lockhart, S. J., and Hocevar, J. (2018). Evidence of Vulnerable Marine Ecosystems documented Via Submarine in the Antarctic Sound and Gerlache Strait (Subarea 48.1). CCAMLR WG-EMM-18/35. Hobart: CCAMLR.

Lockhart, S. J., and Jones, C. D. (2008). Biogeographic patterns of benthic invertebrate megafauna on shelf areas within the Southern Ocean Atlantic sector. CCAMLR Sci. 15, 167-192.

Lockhart, S. J., and Jones, C. D. (2009). Detection of Vulnerable Marine Ecosystems in the Southern Scotia arc (CCAMLR Subareas 48.1 and 48.2) Through Research Bottom Trawl Sampling and Underwater Imagery. CCAMLR WG-EMM-09/32. Hobart: CCAMLR.

Lockhart, S. J., and Jones, C. D. (2010). High Densities of Pterobranchs and Sea Pens Encountered at Sites in the South Orkney Islands (Subarea 48.2): Two Potential VMEs. CCAMLR WG-EMM-10/14. Hobart: CCAMLR.

Lockhart, S. J., Wilson, N., and Lazo-Wasem, E. (2012). Potential VMEs Around Elephant and The South Shetland Islands (Subarea 48.1). Commission for the Conservation of Antarctic Marine Living Resources (CCAMLR) WG-EMM12/51. Hobart: CCAMLR.

Marcon, Y., and Purser, A. (2017). PAPARA(ZZ)I: an open-source software interface for annotating photographs of the deep-sea. SoftwareX. 6, 69-80. doi: 10.1016/j.softx.2017.02.002

Martinez-Dios, A., Dominguez-Carrió, C., Zapata-Guardiola, R., and Gili, J.-M. (2016). New insights on Antarctic gorgonian's age, growth and their potential as paleorecords. Deep Sea Res. I Oceanogr. Res. Papers 112, 57-67. doi: 10.1016/ j.dsr.2016.03.007

Maynou, F., and Cartes, J. (2012). Effects of trawling on fish and invertebrates from deep-sea coral facies of Isidella elongata in the western Mediterranean. J. Mar. Biol. Assoc. U. K. 92, 1501-1507. doi: 10.1017/S0025315411001603

Miller, K. J., Rowden, A. A., Williams, A., and Häussermann, V. (2011). Out of their depth? Isolated deep populations of the cosmopolitan coral Desmophyllum dianthus may be highly vulnerable to environmental change. PLoS One 6:e19004. doi: 10.1371/journal.pone.0019004

Miller, R. J., Hocevar, J., Stone, R. P., and Fedorov, D. V. (2012). Structure-forming corals and sponges and their use as fish habitat in Bering Sea submarine canyons. PLoS One 7:e33885. doi: 10.1371/journal.pone.0033885

Morato, T., Pham, C. K., Pinto, C., Golding, N., Ardron, J. A., Muñoz, P. D., et al. (2018). A multi criteria assessment method for identifying Vulnerable Marine Ecosystems in the North-East Atlantic. Front. Mar. Sci. 5:460. doi: $10.3389 /$ fmars. 2018.00460

Orsi, A. H., Johnson, G. C., and Bullister, J. L. (1999). Circulation, mixing, and production of Antarctic Bottom Water. Prog. Oceanogr. 43, 55-109. doi: 10. 1016/S0079-6611(99)00004-X

Pearman, J. K., Anlauf, H., Irigoien, X., and Carvalho, S. (2016). Please mind the gap - Visual census and cryptic biodiversity assessment at central Red Sea coral reefs. Mar. Environ. Res. 118, 20-30. doi: 10.1016/j.marenvres.2016.04.011

Peck, L. S., and Brockington, S. (2013). Growth of the Antarctic octocoral Primnoella scotiae and predation by the anemone Dactylanthus antarcticus. Deep Sea Res. II Top Stud. Oceanogr. 92, 72-78. doi: 10.1016/j.dsr2.2013.01.024 
Philippi, A. (1858). Beschreibungen einiger neuer Seesterne aus dem Meere von Chiloe. Arch. Naturgesch. 24, 264-268.

QGIS Development Team (2019). QGIS Geographic Information System. Open Source Geospatial Foundation Project. Available Online at: http://qgis.osgeo.org

Ransome, E., Geller, J. B., Timmers, M., Leray, M., Mahardini, A., Sembiring, A., et al. (2017). The importance of standardization for biodiversity comparisons: a case study using autonomous reef monitoring structures (ARMS) and metabarcoding to measure cryptic diversity on Mo'orea coral reefs, French Polynesia. PLoS One 12:e0175066. doi: 10.1371/journal.pone.0175066

Roark, E. B., Guilderson, T. P., Flood-Page, S., Dunbar, R. B., Ingram, B. L., Fallon, S. J., et al. (2005). Radiocarbon-based ages and growth rates of bamboo corals from the Gulf of Alaska. Geophys. Res. Lett. 32:L04606. doi: 10.1029/ 2004GL021919

Roberts, J. M., and Cairns, S. D. (2014). Cold water corals in a changing ocean. Curr. Opin. Environ. Sustain. 7, 118-126. doi: 10.1016/j.cosust.2014.01.004

Rogers, A. D., Baco, A., Griffiths, H., Hart, T., and Hall-Spencer, J. M. (2007). "Corals on seamounts," in Seamounts: Ecology, Fisheries and Conservation, eds T. Pitcher, T. Morato, P. Hart, M. Clark, N. Haggan, and R. Santos (Plymouth: Blackwell Scientific), 141-169. doi: 10.1002/9780470691953.ch8

Rogers, A. D., Clark, M. R., Hall-Spencer, J. M., and Gjerde, K. M. (2008). The Science Behind the Guidelines: A Scientific Guide to the FAO Draft International Guidelines (December 2007) for the Management of Deep-Sea Fisheries in the High Seas and Examples of How the Guidelines may be Practically Implemented. Switzerland: IUCN.

Rogers, A. D., Frinault, B. A. V., Barnes, D. K. A., Bindoff, N. L., Downie, R., Ducklow, H. W., et al. (2019). Antarctic futures: an assessment of climatedriven changes in ecosystem structure, function and service provisioning in the Southern Ocean. Annu. Rev. Mar. Sci. 12, 7.1-7.34. doi: 10.1146/annurevmarine-010419-011028

Siegert, M., Atkinson, A., Banwell, A., Brandon, M., Convey, P., Davies, B., et al. (2019). The Antarctic Peninsula under a $1.5^{\circ} \mathrm{C}$ global warming scenario. Front. Environ. Sci. 7:102. doi: 10.3389/fenvs.2019.00102

Sinclair, D. J., Williams, B., Allard, G., Ghaleb, B., Fallon, S., Ross, S. W., et al. (2011). Reproducibility of trace element profiles in a specimen of the deep-water bamboo coral Keratoisis sp. Geochim. Cosmochim. Acta 75, 5101-5121. doi: 10.1016/j.gca.2011.05.012

Topsent, E. (1916). Diagnoses d'éponges recueillies dans l'Antarctique par le Pourquoi-Pas? Bull. Muséum Natl. D’histoire Nat. Paris 22, 163-172.

Turner, J., Colwell, S. R., Marshall, G. J., Lachlan-Cope, T. A., Carlton, A. M., Jones, P. D., et al. (2005). Antarctic climate change during the last 50 years. Int. J. Climatol. 25, 1147-1148. doi: 10.1002/joc.1130

Turner, J., Lu, H., White, I., King, J. C., Phillips, T., Hosking, J. S., et al. (2016). Absence of $21^{\text {st }}$ century warming on Antarctic Peninsula consistent with natural variability. Nature 535, 411-415.

UNGA. (2007). Resolution 61/105 Sustainable fisheries, including through the 1995 Agreement for the Implementation of the Provisions of the United Nations Convention on the Law of the Sea of 10 December 1982 relating to the Conservation and Management of Straddling Fish Stocks and Highly Migratory Fish Stocks, and related instruments. New York: UNGA.

WoRMS Editorial Board (2021). World Register of Marine Species. Available Online at: https://www.marinespecies.org (accessed August 2, 2020).

Conflict of Interest: The authors declare that the research was conducted in the absence of any commercial or financial relationships that could be construed as a potential conflict of interest.

Publisher's Note: All claims expressed in this article are solely those of the authors and do not necessarily represent those of their affiliated organizations, or those of the publisher, the editors and the reviewers. Any product that may be evaluated in this article, or claim that may be made by its manufacturer, is not guaranteed or endorsed by the publisher.

Copyright $(2021$ Lockhart and Hocevar. This is an open-access article distributed under the terms of the Creative Commons Attribution License (CC BY). The use, distribution or reproduction in other forums is permitted, provided the original author(s) and the copyright owner(s) are credited and that the original publication in this journal is cited, in accordance with accepted academic practice. No use, distribution or reproduction is permitted which does not comply with these terms. 